\title{
Teori Percampuran dan Pertukaran
}

\author{
Sanurdi \\ Dosen Fakultas Hukum dan Syariah \\ Universitas Islam Negeri Mataram \\ sanur-di58@yahoo.co.id
}

\begin{abstract}
This discourse studies sociologically a syariah-based microfinance institute (LKMS) which is usually known as BMT. By applying the framework of new institutionalism, this dissertation utilizes qualitative approach in its data collection. This dissertation chose LKMS in Cipulir, Jakarta and Banda Aceh as its object of study because of socio-cultural and economic differences of both regions. This dissertation found that the profit and loss sharing system at the LKMS is regarded hybrid as it was previously adopted from traditional institution and recontextualized in a new meaning and certain condition. Theoretically, this hybrid mechanism will help traditional institutions become applicable and operational with the modern system of LKMS. This dissertation recommends the government to carry out a policy which is condusive to the development of microfinance institutions fitting with the local culture and religion. Establishment of Islamic banks is driven by the desire to avoid riba in Islamic muamalah activities, establish Islamic ukhuwah among Muslims as well as emotional and physical wellbeing gained through muamalah activities in accordance with religious orders that have ridlo of Allah SWT. This article discourse about that.
\end{abstract}

Keywords: Liqudity, changgeng and Manifest. 


\section{Pendahuluan}

Manusia merupakan makhluk sosial, yaitu makhluk yang selalu berhubungan antara yang satu dengan yang lainnya, karena tidak seorang pun dapat memenuhi kebutuhan hajat hidupnya tanpa pertolongan orang lain. Di dalam masyarakat, manusia mempunyai aktivitas yang beragam baik dalam aspek sosial, politik, ekonomi dan budaya. Keberagaman tindakan dan aktivitas manusia dalam kehidupan sehari-hari tentunya akan berakibat kepada timbulnya suatu ikatan secara hukum. Dalam bidang mu'amalah tindakan yang menimbulkan suatu ikatan secara hukum dapat terlihat pada aktivias jual beli, sewa-menyewa dan sebagainya. Timbulnya suatu ikatan secara hukum diawali dengan suatu tindakan yang dinamakan akad atau transaksi. ${ }^{1}$

Akad atau transaksi menurut syara merupakan ikatan secara hukum yang dilakukan oleh dua orang atau lebih yang sama-sama berkeinginan untuk mengikatkan diri. ${ }^{2}$ Secara garis besar, terdapat dua jenis akad atau transaksi yang seringkali terjadi dan diakui secara syariah yaitu, akad tabarru' (kebaikan) dan akad tijârah (perdagangan). Akad tabarru' merupakan jenis akad dalam transaksi perjanjian antara dua orang atau lebih yang tidak berorientasi profit atau bisnis (non profit oriented). Sedangkan akad tijârah merupakan jenis akad dalam transaksi per-

1 Akad atau transaksi di dalam masyarakat beragam macamnya di antaranya yaitu akad atau transaksi jual beli (jual beli murâbahah, jual beli salam, jual beli mu'ajjal, jual beli istisna', dan jual beli bitsaman 'ajil). Jual beli murâbahah merupakan transaksi jual beli dimana waktu penyerahan barang dan uang dilakukan secara tunai, jual beli salam yaitu transaksi jual beli dimana penyerahan barang dilakukan nanti sementara uang dilakukan di muka, jual beli mu’ajjal merupakan transaksi dimana penyerahan barang dilakukan sekarang sementara penyerahan uang dilakukan secara tangguh, jual beli istisna' merupakan transaksi jual beli dimana penyerahan barang dilakukan nanti sementara penyerahan uang dilakukan di muka secara tangguh ataupun dicicil, dan jual beli bitsaman 'ajil merupakan transaksi jual beli dimana penyerahan barang dilakukan nanti sementara penyerahan uang dilakukan secara dicicil. Lebih detailnya pebahsan tentang jenis-jenis akad di atas, lihat Muhammad, Sistem Operasional Bank Syariah, (Yogyakarta: UII Press, 2000), hlm. 22-33.

2 Dahlan, Abdul Azis (ed.), Ensiklopedi Hukum Islam, Cet. V, Jilid I (Jakarta: Ichtiar Baru Van Hoeve, 2001), hlm. 63. 
janjian antara dua orang atau lebih yang berorientasi profit atau bisnis (profit oriented). ${ }^{3}$ Akad tabarru' digunakan untuk tujuan saling menolong tanpa mengharapkan balsan kecuali dari Allah semata. Dengan demikian, masing-masing pihak yang terlibat tidak dapat mengambil keuntungan (profit) dari jenis transaksi ini. Namun demikian, salah satu pihak mengenakan biaya untuk sekedar menutupi biaya yang muncul akibat transaksi. Sedangkan akad tijârah digunakan dalam transaksi dengan tujuan mengambil keuntungan. Dengan demikian masingmasing pihak yang terlibat dapat mengambil keuntungan (profit) dari jenis transaksi ini.

Untuk memahami transaksi-transaksi yang tergabung dalam akad tabarru' dapat digunakan pendekatan dengan tori pemberian atau meminjamkan suatu obyek tertentu dari satu pihak kepada pihak lainnya. Sedangkan untuk dapat memahami transaksi-transaksi yang tergabung dalam akad tijârah dapat digunakan teori percampuran dan pertukaran. Oleh karena itu, berdasarkan statement di atas yang di-

3 Yang dikategorikan sebagai akad tabarru' adalah qard, rahn, hawâlah, wakâlah, wadiah, kafâlah, dan hibbah dan wakaf. Qard merupakan transaksi peminjaman dimana salah satu pihak meminjamkan suatu obyek yang berbentuk uang, Rahn merupakan transaksi yang dilakukan oleh dua orang atau lebih dimana salah satu pihak meminjamkan suatu obyek yang berbentuk uang yang disertai jaminan, Hawâlah merupakan transaksi yang dilakukan oleh dua orang atau lebih dimana salah satu pihak meminjamkan suatu obyek berbentuk uang untuk mengambil alih piutang atau hutang dari pihak lain, wakâlah merupakan akad atau transaksi yang dilakukan oleh salah satu pihak atau lebih dimana salah satu pihak meminjamkan obyek yang berbentuk jasa atau dapat juga disebut meminjamkan dirinya untuk melakukan sesuatu atas nama diri pihak lain, wadiah merupakan transaksi yang dilakukan oleh salah satu pihak atau lebih dimana salah satu pihak memberikan suatu obyek yang berbentuk jasa yang lebih spesifik yakni custodian (penitipan atau pemeliharaan)., kafâlah merupakan transaksi yang dilakukan oleh dua orang atau lebih dimana salah satu pihak memberikan suatu obyek yang berbentuk jaminan atau kejadian tertentu dimasa yang akan datang, hibah merupakan transaksi yang dilakukan oleh dua pihak atau lebih dimana salah satu pihak memberikan suatu obyek yang berbentuk uang ataupun obyek lainnya tanpa disertai kewajiban mengembalikan, sementara jika obyek tersebut diberikan kepada Allah sehingga tidak dapat diperjualbelikan, maka transaksi tersebut dinamakan wakaf. Lihat Sunarto Zulkifli, Panduan Praktis Transaksi Perbankan Syariah, (Jakarta: Zikrul Hakim, 2003), hlm. 13-15. 
fokuskan dalam pembahasan makalah ini adalah teori percampuran dan pertukaran dengan tidak mengabaikan teori peminjaman atau pemberian. Kemudian pengamplikasian teori-teori tersebut di dalam perbankan syariah.

Urgensi pembahasan ini karena, pertukaran merupakan hal yang pokok dalam bidang ekonomi karena dapat mengatur dan menyelesaikan masalah pemakaian dan produksi. Dalam dunia modern sistem pertukaran sangat diperlukan dalam kehidupan, karena setiap orang tidak dapat memproduksi semua kebutuhan hidupnya tanpa hal tersebut

\section{Transaksi alias Akad}

Akad tijârah digunakan dalam transaksi dengan tujuan mencari keuntungan. Dengan demikian, masing-masing pihak yang terlibat dapat mengambil keuntungan (profit) dari jenis transaksi ini. Besarnya keuntungan yang diperoleh ditentukan oleh kesepakatan masing-masing pihak yang terlibat. Meskipun berorientasi bisnis untuk menghasilkan profit, namun akad tijârah ini dapat diubah menjadi akad tabarru' (kebaikan) apabila pihak yang haknya tertahan ikhlas melakukannya. Sebaliknya, akad tabarru' tidak boleh diubah menjadi akad tijârah. ${ }^{4}$

\footnotetext{
4 Sebagai ilustrasi dalam hal ini adalah: jika Bapak Muhammad yang berprofesi sebagai dosen teladan seluruh Indonesia dengan gaji tetap di UIN Sunan Kalijaga (Pasca Sarjana), maka Bapak Muhammad sebenarnya tengah melakukan akad tijârah dengan UIN Sunan Kalijaga (Pasca Sarjana), karena ada kesepakatan peroleh gaji yang besarnya tertentu. Namun demikian, pada saat UIN Sunan Kalijaga (Pasca Sarjana) tengah kesulitan keuangan, dengan akhlaknya yang mulia sebagai seorang muallaf, Bapak Muhammad dapat saja mengubah akadnya menjadi tabarru' dengan memperkenankan sekolah untuk tidak membayarkan gajinya. Aisar Muhammad Akram yang menawarkan dirinya untuk menyeberangkan seorang ibu di area lalu lintas, depan Mall Saphire Square, sebenarnya telah melakukan akad tabarru' dengan sang ibu. Namun tidak bisa tiba-tiba di tengah jalan Aisar meminta upah atas jasanya itu. Jika saja sejak awal Aisar ingin memperoleh upah, maka sebaiknya dilakukan akad I diawal transaksi saat menawarkan diri, misalnya jika ibu dapat saya antar hingga seberang jalan maka ibu harus membayar upah saya sebesar Rp. 1000,00. Lihat Sunarto Zulkifli, Panduan Praktis Transaksi Perbankan Syariah, (Jakarta: Zikrul Hakim, 2003), hlm. 16.
} 
Akad atau transaksi yang terangkum dalam akad tijârah dapat dibagi menjadi dua bagian, pembagian ini dapat dilihat berdasarkan tingkat kepastian dari hasil yang diperolehnya, yaitu natural certainty contracts dan natural uncertainty contracts.

Natural certainty contracts merupakan transaksi atau akad dalam bisnis yang memberikan kepastian pembayarannya, baik dari segi jumlah (amount) maupun waktu (timing)-nya. ${ }^{5}$ Sedangkan menurut Zulkifli Sunarto natural certainty contract merupakan suatu jensi kontrak transaksi dalam bisnis yang memiliki kepastian keuntungan dan pendapatan baik dari segi jumlah maupun waktu penyerahannya. Yang dimaksud dengan memiliki kepastian adalah masing-masing pihak yang terlibat dapat melakukan prediksi terhadap pembayaran maupun waktu pembayarannya. ${ }^{6}$

Sedangkan karakter teransaksi oleh ahli dalam ekonomi Islam dan perbankan Islam telah telah memberikan ciri atau karakteristik terhadap transksi natural certainty contracts, dengan tujuan untuk memberikan kemudahan dalam mengidentifikasi macam dan jenis transaksi ini. Adapun ciri-ciri yang dimaksud adalah:

1. Cash flow-nya bisa diprediksi dengan relatif pasti. Karena sudah disepakati oleh kedua belah pihak yang bertransaksi di awal akad.

2. Kontrak-kontrak ini secara sunnatullah (by their nature) menawarkan return yang tetap dan pasti, jadi sifatnya fixed and predetermined.

3. Obyek pertukaran (baik barang maupun jasa) pun harus ditetapkan di awal akad dengan pasti, baik jumlahnya (quantity), mutunya (quality), harganya (price), dan waktu penyerahannya (time of delivery).

4. Yang termasuk dalam kategori ini adalah jual beli, upah-mengupah, sewa-menyewa, dan lain-lainnya.

\footnotetext{
5 Sunarto Zulkifli, Panduan..., hlm. 16.

6 Sunarto Zulkifli, Panduan..., hlm. 16.
} 
5. Dalam kontrak jenis ini, pihak-pihak yang bertransaksi saling mempertukarkan asetnya (baik real assets maupun financial assets). Jadi masing-masing pihak tetap berdiri sendiri (tidak saling bercampur membentuk usaha baru). Sehingga tidak ada pertanggungan resiko bersama. ${ }^{7}$

\section{Klasifikasi Berdasarkan Objek Pertukaran}

Transaksi natural certainty contract apabila dilihat berdasarkan obyek atau benda yang dipertukarkan dapat diklasifikasikan menjadi tiga macam, yaitu:

\section{Pertukaran Real Asset ('Ayn) dengan Real Asset ('Ayn)}

Dalam mempertukarkan suatu barang dengan barang terkadang ada yang jenis barangnya sama dan ada yang jenis barangnya berbeda, oleh karena itu pertukaran jenis barang ini terbagi dua, yaitu: pertama, Jenis berbeda. Dalam pertukaran 'ayn dengan 'ayn, bila jenisnya berbeda (misalnya upah tenaga kerja yang dibayar dengan sejumlah beras), maka tidak ada masalah (dibolehkan). Kedua, Jenis sama. Dalam pertukaran yang jenisnya sama, maka fiqh membedakan antara real asset yang secara kasat mata dapat dibedakan mutunya dengan real asset yang secara kasat mata tidak dapat dibedakan mutunya. Pertukaran sapi dengan sapi, kambing dengan kambing, kerbau dengan kerbau diperbolehkan karena secara kasat mata dapat dibedakan mutunya. Sedangkan pertukaran gandum dengan gandum, manggis dengan manggis, salak dengan salak dilarang karena secara kasat mata tidak dapat dibedakan mutunya.

Satu-satunya kondisi yang membolehkan pertukaran antara yang sejenis dan secara kasat mata tidak dapat dibedakan mutunya adalah: Sawa-an bi sawa-in (sama jumlahnya), Mistlan bi mistlin (sama mutunya), dan Yadan bi yadin (sama waktu penyerahannya) ${ }^{8}$

7 Adiwarman Karim, Bank Islam Analisis Fiqh dan Keuangan, (Jakarta: PT. Raja Grafindo Persada, 2004), hlm. 43.

8 Adiwarman Karim, Bank Islam..., hlm. 43. 
2. Pertukaran Real Asset ('Ayn) dengan Financial Asset (Dayn)

Bentuk pertukaran antara barang dengan selain barang dalam hal ini bisa berupa uang dan jasa, dapat dibedakan ke dalam dua bentuk, yaitu: (1) Bila real asset-nya adalah barang, maka pertukaran semacam itu dinamakan jual beli (al-bai). ${ }^{9}$ (2) Bila real assetnya ('ayn-nya) adalah jasa maka pertukaran itu disebut sewa-menyewa atau upah-mengupah (al-ijarah). Ijarah adalah lease contract dimana satu bank atau lembaga keuangan menyewakan peralatan (equipment) kepada salah satu nasabahnya berdasarkan pembebanan biaya yang sudah ditentukan secara pasti sebelumnya (fixed charge). ${ }^{10}$

\section{Pertukaran Financial Asset (Dayn) dengan Financial Asset (Dayn)}

Sistem pertukaran financial asset (dayn) dengan financial asset (dayn) dibedakan ke dalam bentuk berupa (a) Uang ${ }^{11}$ dan (b) Surat ber-

${ }^{9}$ Kalau dilihat berdasarkan metode pembayaranya, Islam membolehkan jual beli dengan tiga cara, yaitu:

- Secara tunai (now for now).

- Secara tangguh bayar (deferred payment-bai' muajjal). Contoh jual beli model ini adalah jual beli secara murâbahah, dengan penagguhan 1 bulan, 3 bulan, 1 tahun dan seterusnya. Pembiyaan ini diberikan kepada nasabah dalam rangka pemenuhan produksi (inventory). Lihat Karnaen Parwataatmadja \& Muhammad Syafi'i Antonio, Apa dan Babaimana Bank Islam, (Yogyakarta: PT. Dana Bhakti Prima Yasa, 1992), hlm. 25.

- Secara tangguh serah (deferred delivery-bai' salam). Jual beli tangguh serah dapat dibedakan lagi menjadi, (1) bai' al-salam yaitu pembayaran dilakukan secara advance manakala penyerahan barang dilakukan kemudian, (2) bai' al-istisna', yaitu kontrak order yang ditandatangani bersama antara pemesan dengan produsen untu pembuatan suatu jenis barang tertentu atau suatu perjanjian jual beli dimana barang yang diperjualbelikan belum ada. Lihat Muhammad, Sistem dan Prosedur Operasional Bank Syariah, (Yogyakarta: UII Press, 2005), hlm. 31.

${ }^{10}$ Heri Sudarsono, Bank dan Lembaga Keuangan Syariah Deskrifsi dan Ilustrasi, (Yogyakarta: Ekonosia, 2004), hlm. 66.

${ }^{11}$ Dalam bentuk uang. (1) Pertukaran uang yang sejenis, hanya dibolehkan bila memenuhi syarat: sawa-an bi sawa-in (same quantity) dan yadan bi yadin (same time 
harga. Jual beli surat berharga (bai' al-dayn bi al-dayn) pada dasarnya tidak diperbolehkan, tapi bila surat berharga dilihat lebih rinci dapat dibedakan menjadi:

a. Penjualan kepada si penghutang (bai' al-dayn lil madin, sale of debt to the debtor) yang dapat dibedakan lagi menjadi: pertama, hutang yang pasti pembayarannya (comfirmed, mustaqir). Bagi mazhab Hambali dan Zahiri, transaksi ini boleh. Kedua, hutang yang tidak pasti pembayarannya (uncomfirmed, ghairu mustaqir) transaksi ini dilarang.

b. Panjualan kepada pihak ketiga (bai' al dayn lil ghairu madin, sale of debt to third party). Para ulama dalam hal ini berbeda pendapat, pertama, kebanyakan ulama mazhab Hanafi dan Syafii serta beberapa ulama mazhab Hanbali dan Zahiri secara tegas tidak membolehkan hal ini. Kedua, Ibnu Taimiyah membolehkan bila hutangnya adalah hutang yang pasti pembayarannya (comfirmed, mustaqir). Ketiga, Imam Siraji, Subki dan Nawawi membolehkannya dengan tiga syarat. Keempat, Imam Anas bin Malik dan Zarqani membolehkannya dengan delapan syarat. $^{12}$

c. Waktu pertukaran. Para ulama dalam melihat waktu pertukaran dengan transksi natural certainty contracts ini yang kemudian dikodifikasikan dalam skim ilmu fiqih membedakannya menjadi dua waktu pertukaran transaksi (NCC), yaitu:

of delivery). Contoh pertukaran uang satu lembar pecahan Rp. 100.000,00. dengan 10 lembar uang pecahan Rp. 10.000,00. harus dilakukan penyerahannya pada saat yang sama. (2) Pertukaran uang yang tidak sejenis, hanya dibolehkan bila memenuhi syarat yadan bi yadin (same time of delivery). Transaksi ini disebut sharf (money changer). Contoh pertukaran USD 1000 dengan Rp. 10.000.000,00. harus diserahkan pada saat yang sama.

${ }^{12}$ Adi Warman Karim, Bank Islam.., hlm. 50. Beberapa persyaratan yang disyaratkan oleh para ulama di atas bisa dibaca dalam buku atau referensi yang sama dan pada halaman yang sama. 
1) Naqdan (immediet delivery) yang berarti kondisi dimana waktu pertukaran dilakukan secara tunai, segera atau sekarang (present), penyerahan saat itu juga.

2) Ghairu naqdan (defferred delivery) yang berarti kondisi dimana waktu penyerahannya dilakukan masa mendatang atau penyerahan kemudian..$^{13}$

Dari unsur-unsur pertukaran di atas dapat dibuat matriks pertukaran sebagaimana tercantum pada tabel 1 . Dalam matriks tersebut kemudian bisa diklasifikasikan kembali jenis-jenis pertukaran yang diperbolehkan secara syariah dan yang tidak diperbolehkan. Untuk mendapatkan gambaran tentang transksi pertukaran lihat tabel 1 pada daftar lampiran tabel. Transaksi pertukaran yang penyerahannya dilakukan pada masa yang akan datang tidak diperbolehkan, karena hal ini sama saja saling mempertukarkan sesuatu yang tidak jelas kondisinya dimasa mendatang. Akan muncul kemungkinan kerugian salah satu pihak dimasa yang akan datang. Kemudian untuk lebih memberikan pemahaman mengenai teori pertukaran, lihat tabel 2 pada daftar tabel.

\section{Aplikasi Teori Pertukaran dan Percampuran dalam Islam}

Berdasarkan teori yang teleh diutarakan dalam pembahasan di atas, selanjutnya dalam pembahasan ini akan diuraikan penerapan kedua teori tersebut dalam praktiknya berdasarkan Islam. Yang pertama dilihat dalam uraian ini adalah pertukaran kemudian percampuran.

\section{a. Pertukaran}

Pertukaran di dalam dunia usaha saat ini biasa dikenal dengan istilah lain yaitu jual beli. Secara etimologis jual beli adalah tukar-menukar harta dengan harta. Sedangkan secara terminologis adalah transaksi pertukaran antara 'ayn yang bertbentuk barang dengan dayn yang ber-

\footnotetext{
${ }^{13}$ Sunarto Zulkifli, Panduan..., hlm. 16.
} 
bentuk uang, ${ }^{14}$ transaksi ini lazim disebut transaksi jual beli. Di dalam al-Qur'an terdapat berbagai ayat yang menghukumi jual beli sebagai aktifitas muamalah yang dihalalkan seperti firman Allah dalam surat al-Baqarah ayat 282 dan $275 .{ }^{15}$

Berdasarkan teks ayat tersebut dapat diketahui bahwa jual beli sebagai suatu transaksi dan sekaligus aktivitas ummat manusia merupakan perbuatan yang halal lagi mulia. Dengan berkembangnya dan meluasnya pengetahuan para ahli fiqih dan majunya perkembangan bidang ekonomi, jual beli di sini memiliki pembagian berdasar pada objek dagangan dan sisi cara standarisasi harga, yaitu: Klasifikasi jual beli dari sisi objek dagangan. Ditinjau dari sisi ini, jual beli dibagi menjadi tiga jenis. Pertama, jual beli umum, yaitu menukar uang dengan barang. Kedua, jual beli ash-sharf atau money changer, yaitu penukaran uang dengan uang. Ketiga, jual beli muqayyadah atau barter, yaitu menukar barang dengan barang.

Klasifikasi jual beli dari sisi cara standarisasi harga:

a. Jual beli barginal (tawar-menawar). Yakni jual beli dimana penjual tidak memberitahukan modal barang yang dijualnya.

b. Jual beli amânah. Yakni jual beli dimana penjual memberitahukan harga modal jualnya. Dengan dasar jual beli ini jenis jual beli tersebut terbagi lagi menjadi tiga jenis, yaitu: (1). Jual beli murâbahah. Yakni jual beli dengan modal dan keuntungan yang diketahui. (2) Jual beli wadhi'ah. Yakni jual beli dengan harga di bawah modal dan jumlah kerugian yang diketahui.

c. Jual beli tauliyah. Yakni jal beli dengan menjual barang dalam harga modal, tanpa keuntungan dan kerugian. Jual beli mujayadah (lelang). Yakni jual beli dengan cara penjual menawarkan barang dagangannya, lalu para pembeli saling menawar dengan

\footnotetext{
${ }^{14}$ Sunarto Zulkifli, Panduan..., hlm. 38.

${ }^{15}$ Bunyi masing-masing ayat al-Qur'an tersebut di atas adalah (1)“Dan persaksikanlah apabila kamu berjual beli" dan (2) "Allah telah menghalalkan jual beli dan mengharamkan riba” lihat Al- Qur'an dan Terjemahan, Departemen Agama RI, (Surabaya: PT. Surya Cipta Aksara, 1993), hlm. 69 dan 70.
} 
menambah jumlah pembayaran dari pembeli sebelumnya, lalu si penjual denga harga tertinggi dari pembeli tersebut. Kebalikannya disebut dengan jual beli munaqadah. ${ }^{16}$

Pembagian jual beli dilihat dari cara pembayaran

Dilihat dari cara pembayarannya, jual beli dapat diklasifikasikan menjadi tiga bagian, yaitu:

1) Bai' bithaman 'ajil. Yakni menjual dengan harga asal ditambah dengan margin keuntungan yang telah disepakati dan dibayar secara kredit, dengan ketentuan sebagai berikut: (1) Harga barang dapat ditentukan lebih tinggi dari transaksi tunai yang telah disepakati dan tidak dapat dirubah. (2) Waktu pembayaran ditentukan berdasarkan kesepakatan kedua belah pihak. (3) Bila nasabah tidak dapat membayar tepat pada waktunya kebijakan diambil oleh pihak pembuat kebijakan, kebijakan apapun tidak mengenakan sanksi dari akad yang sama. ${ }^{17}$

2) Bai' as-salam. Yakni prinsip jual beli suatu barang tertentu oleh pihak penjual dan pembeli dengan harga pokok ditambah keuntungan yang disepakati, dimana penyerahan barang dilakukan dikemudian hari sementara uang diserahkan di muka.

3) Bai' al-istishna adalah salah satu pengembangan prinsip bai' as-salam, di mana waktu penyerahan barang dilakukan dikemudian hari sementara pembayaran dapat dilakukan melalui cicilan atau ditangguhkan. ${ }^{18}$

\footnotetext{
${ }^{16}$ Adiwarman Karim, Bank Islam, (Jakarta: ISBN, 2004), hlm. 89. Lihat juga Muhammad, Sistem dan Prosedur Oprasional Bank Syariah, (Yogyakarta: UII Press, 2005), hlm. 22.

${ }^{17}$ Muhammad, Sistem dan Prosedur Oprasional Bank Syariah, (Yogyakarta: UII Press, 2005), hlm. 31.

${ }^{18}$ Sunarto Zulkifli, Panduan Praktis, (Jakarta: Zikrul Hakim, 2003), hlm. 41.
} 


\section{b. Percampuran}

Percampuran ini bisa terjadi karena kurangnya kemampuan untuk mendirikan suatu usaha sehingga membutuhkan kerja sama (musyarakah) dari pihak lain. Dalam hal ini al-Qur'an telah menegaskan, "Sesungguhnya kebanyakan dari orang-orang yang berkongsi itu sebagian mereka berbuat zolim kepada sebagian lain kecuali orang-orang yang briman dan mengerjakan amal shaleh" (Q.S. As-Shad: 24). ${ }^{19}$

Dengan kekurangan baik dari segi modal maupun kemampuan dalam hal ini keahlian, maka para pihak yang hendak melakukan sebuah transaksi menerapkan beberapa cara yang dapat memudahkan bagi mereka, cara-cara tersebut yaitu musyarakah atau syirkah.

1) Definisi syirkah. Syirkah adalah keikutsertaan dua orang atau lebih dalam suatu usaha tertentu dengan sejumlah modal yang telah ditetapkan berdasarkan perjanjian untuk bersama-sama menjalankan keuntungan dan kerugian dalam bagian yang telah ditentukan. Dalam pengertian lain merupakan akad kerja sama di antara pemilik modal yang mencampurkan modal untuk tujuan mencari keuntungan. Sedangkan dalam dunia perbankan merupakan perjanjian pembiayaan antara bank dengan pengusaha dimana pihak bank ataupun pengusaha secara bersama pula atas dasar bagi hasil sesuai dengan kesepakatan. ${ }^{20}$

2) Pembagian syirkah. Syrkan dibagi atas: (1) Syirkah amlak, yakni suatu perkongsian yang tidak memerlukan perjanjian melainkan berjalan dengan sendirinya. ${ }^{21}$ (2) Syirkah uqud, yaitu per-

19 Al-Qur'an dan Terjemahannya, Depag RI, ( Surabaya: Surya Cipta Aksara, 1993), hlm. 38 .

${ }^{20}$ Najatullah Siddiqi, Kemitraan Bagi Usaha dan Bagi Hasil dalam Hukum Islam, (Yogyakarta: Dhana Bakti Prima Yasa, 1996), hlm. 8. Lihat pula Karnaen Perwataatmadja dan Muahammad Syafii Antonio, Apa dan Bagaimana Bank Islam, (Yogyakarta, PT. Dhana Bhakti Prima Yasa, 1992), hlm. 78.

${ }^{21}$ Dalam perkembangan selanjutnya syirkah 'uqud diklasifikasikan menjadi dua yaitu: (1) Amlak jabr, yakni perkongsian yang terjadi secara otomatis dan paksa, otomatis berarti tidak memerlukan kontrak untuk membentuknya, paksa berarti tidak 
kongsian yang terbentuk karena suatu kontrak. Syirkah 'uqud dilihat berdasarkan aspek perkongsiannya terbagi lagi kepada beberapa bagian, yaitu:

i. Syirkah inan atau limited kompani, merupakan persekutuan dalam modal, usaha dan keuntungan, kerjasama antara dua orang atau lebih dengan modal yang mereka miliki bersama untuk membuka usaha yang mereka lakukan lalu berbagi keuntungan bersama.

ii. Syirkah mufawadah, yakni setiap kerjasama di mana masingmasing pihak yang beraliansi memiliki modal, usaha dan hutang piutang yang sama dari mulai berjalannya kerja sama sampai akhir.

iii. Syirkah wujuh, yakni setiap anggota hanya mengandalkan wibawa dan nama baik dan unsur modal tidak diperhitungkan. Pembagian keuntungan dan kerugian berdasarkan negosiasi diantara anggotanya.

iv. Syrikah abdan, yakni kerjasama dimana dua orang atau lebih yang berdekatan bentuk kerjanya menerima pesanan dari pihak ketiga dan membagi keuntungan melalui negosiasi bersama.

v. Mudharabah, yakni suatu perkongsian antara dua pihak dimana pihak pertama (shahib al-mal) menyediakan dana dan pihak kedua (mudharib) bertanggung jawab atas pengelolaan usaha. ${ }^{22}$

Berdasarkan keterangan-keterangan di atas, syirkah dalam skema fiqh mu'amalah bisa dilihat dalam daftar tabel 5 terlampir. Sedangkan tabel 6 tentang skema pembiayaan al-Musyârakah.

ada pilihan untuk menolaknya. Hal ini biasa terjadi dalam kewarisan. (2) Amlak ikhtiar, yakni perkongsian yang terbentuk karena suatu kontrak.

${ }^{22}$ Sunarto Zulkifli, Panduan.., hlm. 55. 


\section{Penutup}

Berdasarkan tingkat kepastian dari hasil yang diperoleh, akad tijarah dapat diklasifikasikan menjadi dua yang selanjutnya dikenal dengan teori pertukaran (natural certainty contract) dan teori percampuran (natural uncertainty contract). Natural certainty contract merupakan akad dalam bisnis yang memiliki kepastian keuntungan dan pendapatan baik dari segi jumlah maupun waktu penyerahannya.

Transaksi ini dicirikan dengan cash flow dan return-nya relatif pasti. Teori pertukaran terdiri dari dua pilar yaitu objek pertukaran dan waktu pertukaran. Berdasarkan objek pertukarannya, dapat diklasipikasikan menjadi tiga jenis yaitu, pertukaran real asset ('ayn) dengan real asset ('ayn), pertukaran real asset ('ayn) dengan financial asset (dayn) dan pertukaran dengan financial asset (dayn). Sedangkan waktu pertukaran fiqih membedakannya menjadi dua, yaitu naqdan (imediet delivery) dan ghairu naqdan (deferred delivery). Sedangkan natural uncertainty contract merupakan akad yang tidak memberikan kepastian pendapatan baik dari segi jumlah maupun waktu penyerahnya. Transaksi ini dicirikan dengan return-nya bisa positif, negatif atau nol. Dalam hal ini hasilnya tidak pasti dan bersifat fluktuatif dan berlaku pada kontrak-kontrak investasi.

Transaksi pertukaran secara aplikatif dalam dunia usaha lazim disebut jual beli, yakni transaksi pertukaran antara 'ayn yang berbentuk barang dan dayn yang berbentuk uang. Sedangkan transaksi percampuran sesuai dengan istilahnya yaitu aktivitas menyatukan barang atau modal untuk mencari keuntungan antara dua orang atau lebih, maka transaksi ini dalam bidang muamalah lazim disebut musyarakah. 


\section{Daitar Pustaka}

Dahlan, Abdul Azis (ed.). Ensiklopedi Hukum Islam, Cet. V, Jilid I. Jakarta: Ichtiar Baru Van Hoeve, 2001.

Depag RI. Al-Qur'an dan Terjemahannya. Surabaya: Surya Cipta Aksara, 1993.

Karim, Adiwarman. Bank Islam Analisis Fiqh dan Keuangan. Jakarta: PT. Raja Grafindo Persada, 2004

Muhammad. Sistem dan Prosedur Oprasional Bank Syariah. Yogyakarta: UII Press, 2005.

Perwataatmadja, Karnaen \& Muahammad Syafii Antonio, Apa dan Bagaimana Bank Islam. Yogyakarta: PT. Dhana Bhakti Prima Yasa, 1992.

Siddiqi, Najatullah. Kemitraan Bagi Usaha dan Bagi Hasil dalam Hukum Islam. Yogyakarta: Dhana Bakti Prima Yasa, 1996.

Sudarsono, Heri. Bank dan Lembaga Keuangan Syariah Deskripsi dan Ilustrasi. Yogyakarta: Ekonosia, 2004.

Zulkifli, Sunarto. Panduan Praktis Transaksi Perbankan Syariah. Jakarta: Zikrul Hakim, 2003. 